\title{
The 'Frail Researcher' in dialogue with existential phenomenology: The threat of empiricism within the quest for sound methodology in practical theological research
}

\begin{tabular}{|c|c|}
\hline $\begin{array}{l}\text { Author: } \\
\text { Daniël J. Louw }\end{array}$ & \\
\hline $\begin{array}{l}\text { Affiliations: } \\
{ }^{1} \text { Faculty of The } \\
\text { University of S } \\
\text { South Africa }\end{array}$ & $\begin{array}{l}\text { ology, } \\
\text { tellenbosch, }\end{array}$ \\
\hline $\begin{array}{l}{ }^{2} \text { Faculty of The } \\
\text { North-West Ur } \\
\text { Potchefstroom } \\
\text { South Africa }\end{array}$ & $\begin{array}{l}\text { ology, } \\
\text { niversity, } \\
\text { Campus, }\end{array}$ \\
\hline $\begin{array}{l}\text { Corresponding } \\
\text { Daniël Louw, } \\
\text { djl@sun.ac.za }\end{array}$ & author: \\
\hline $\begin{array}{l}\text { Dates: } \\
\text { Received: } 21 \mathrm{~F} \\
\text { Accepted: } 29 \\
\text { Published: } 03\end{array}$ & $\begin{array}{l}\text { eb. } 2018 \\
\text { May } 2018 \\
\text { Sept. } 2018\end{array}$ \\
\hline $\begin{array}{l}\text { How to cite th } \\
\text { Louw, D.J., } 201 \\
\text { Researcher' in } \\
\text { existential phe } \\
\text { The threat of } \\
\text { within the que } \\
\text { methodology i } \\
\text { theological res } \\
\text { Skriflig } 52(1) \text {, } \\
\text { doi.org/10.41C } \\
\text { v52i1.2361 }\end{array}$ & $\begin{array}{l}\text { is article: } \\
\text { 18, 'The 'Frail } \\
\text { dialogue with } \\
\text { nomenology: } \\
\text { empiricism } \\
\text { st for sound } \\
\text { in practical } \\
\text { earch', In die } \\
\text { a2361. https:// } \\
\text { O2/ids. }\end{array}$ \\
\hline $\begin{array}{l}\text { Copyright: } \\
\text { (c) 2018. The A } \\
\text { Licensee: AOSI } \\
\text { is licensed und } \\
\text { Creative Comn } \\
\text { Attribution Lic }\end{array}$ & $\begin{array}{l}\text { uthors. } \\
\text { IS. This work } \\
\text { ler the } \\
\text { nons } \\
\text { ense. }\end{array}$ \\
\hline Read online: & \\
\hline 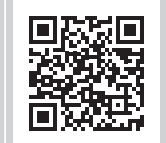 & $\begin{array}{l}\text { Scan this QR } \\
\text { code with your } \\
\text { smart phone or } \\
\text { mobile device } \\
\text { to read online. }\end{array}$ \\
\hline
\end{tabular}

Within an academic environment and context of higher education, the question of disciplinary differentiation and research methodology are burning issues to adhere to the quest for scientific and sound epistemological based knowledge. While dealing with the dual tension: wisdom (sapientia) and reason (scientia), it is difficult for practical theology to identify and maintain its theological character. Under the pressure of human sciences, research in practical theology tends to turn to phenomenology so to gain clarity on the philosophical framework or paradigm for performing research projects in a systematic and methodological way. In this regard, existential phenomenology probes into the meta-realm of meaning-giving; it describes the frailty of life in terms of being (Dasein) as exposed to anxiety, dread, despair and fear of death. Due to the demand for empirical research, the threat of empiricism and the danger of Platonification (the 'causation trap') is discussed. To maintain both its spiritual-theological character (ministerial and ecclesial context), and its relevancy for the dynamics of life events (contextuality), a 'spiritual empiricism' is proposed by means of a praxis of practical theological verbing, namely understanding and interpreting, communicating and verbalising, acting, hoping, imagining, seeing, beautifying and living. It is argued that the notion 'praxis of God' could serve as theological paradigm in theory formation. The passio Dei is both a spiritual matter and existential-experiential entity within the encounter of God-human beings. It refers to both the reason or logic of God (hesed) and the wisdom of grace (compassion).

\section{Introduction}

It is indeed a question whether theology could be rendered as a scientific endeavour. Could data, derived from religious sources, be categorised and classified as 'research' within an academic environment?

The perception is often that academic theology and a scientific approach to biblical data rob theological students from their naivety and faith. The contra-argument is then that theology is about faithful devotion and the formation of disciples, and not skilled theologians and scientific researchers.

Should theology therefore not rather be taught at a seminary and run by a church denomination?

At stake is spiritual formation and not theory formation within the confines of a university. Theological education should therefore be taught in the exclusive space of a 'monastery' or 'seminary', and not in the academic classrooms of higher education with its emphasis on quality and outcomes that adhere to the criteria of scientific knowledge and critical reflection.

The fear is that science with its epistemic demand of rational based knowledge by means of critical analyses as well as the positivistic emphasis on verified data, could become prescriptive for the transcendent realm of faith and the spiritual formation of 'human souls'. Immediately we are back to the traditional tension: faith versus reason. Within research methodology the Thomas Aquinas formula of fides quaerens intellectum (Migliore 2004) raises the question: Can the scientific quest for rational analyses (intellectum) be merged with the spiritual dimension of faithful devotion (fides) and the beatific healing of life: fides quaerens beatitudinem?

Besides the tension between faith and reason, another tension developed, namely the tension between belief and practice. After the enlightenment, it became a challenge in postmodern thinking 
(Hernandez 2006:60) how to merge faith and practice. In the quest for an authentic Christian life, the quest is about congruence between the truths asserted and the life lived. In his outline on the spirituality of Henri Nouwen, Hernandez (2006:60) remarks as follows: 'Belief and practice, like doctrine and experience, need to be intentionally merged because they belong together just as theology and spirituality are connected tightly together.'

Can a praxis approach with the focus on human needs and cultural contexts still reckon with spiritual needs and the human quest for hope and meaning (the telic dimension in life)? Can the discourse with existential phenomenology help practical theology to move beyond the threat of empiricism (epistemology in practical theology is solely dependent on empirical data derived from human experience and behavioural analyses, interviews and case studies) to an existential analysis and spiritual hermeneutics that reckon with the noetic and meaning dimension of life experiences? If the latter include religious experiences, how then can research in practical theology maintain its theological character? Is it possible that the notion of the 'praxis of God' can be helpful in this regard?

\section{Reasonable faith in practical theological research}

How 'reasonable' is faith-based knowledge?

The formulation by Thomas Aquinas, ${ }^{1}$ namely that theology is about faith seeking understanding (fides quaerens intellectum), had become a classical definition and framework for scientific research in Christian theology.

In his book Religion before dogma: Groundwork in practical theology (2007), the practical theologian Douglas McGaughey points out that conceptualisation cannot take place without the rational factor. According to him (McGaughey 1998) paradigmatic frameworks and models are cognitive:

Since models are mental models of reality, we appropriately speak of models as 'cognitive'. The use of the term cognitive here does not suggest, however, that models are rational in the sense of necessarily logical. (p. 18)

In critical reflection and theory formation, a kind of mental consciousness and critical reasoning play a fundamental role. As McGaughey (1998:157) aptly points out: 'Empiricism or objective actual reality is not to be contrasted with feeling and intuition but complemented by critical understanding.'

According to van der Ven (2002:23), it is therefore a false dilemma to juxtapose an empirical approach and a normative

1.Thomas holds that human reason, unaided by revelation, can not only tell us thing about the natural world, but also can provide and austere account of the existence of God. Thomas also holds that reason plays a vital role within theology. Indeed, it of God. Thomas also holds that reason plays a vital role within theology. Indeed, it must have a role to play if sacra doctrina is to be scientia. Thomas is not willing to say that holy teaching is simply a matter of believing a collection of bits of information that God has revealed. If it is true scientia, then reason must have 'faith ro to play in this activity. It must be a process of, to use St Anselm's phrase, 'faith seeking understanding' (fides quaerens intellectum), in which understanding involves some sort of seeing-the-whole by the interrelatedness of the parts (Bauerschmidt 2013:143). approach, and to separate them in theory formation for practical theological reflection. Without any doubt, the empirical dimension of practical theology includes a normative as well as rational dimension.

The notion of experience, feeling and a theory that operates on the guidelines for the praxis of ministerial activities (the praxis of church operations) was already pointed out by Friedrich Schleiermacher. Faith must become a 'lived religion'. For Schleiermacher, practical theology is basically a 'technology' (Technik) within the dynamics of religious experiences (Burkhart 1983:48).

Central in Schleiermacher's exposition of the concept 'schlechthinniges Abhängigskeitsgefühl', is the concept of life as an awareness of God's penetration of life by means of habitus. Habitus as a religious category represents an acute sense of God's presence that impact on the praxis and quality of 'Sosein' (qualitative mode of being in this world). With self-awareness (self-consciousness) is meant the connection between mode of being (Sosein) and a co-working factor that determine our sensible receptiveness (Empfänglichkeit) (empirical dimension) and character (identity). Within this causality and mutuality between God and our being, a pious feeling of dependency is established (Schleiermacher 1980:31).

According to Dillen and Gärtner (2015:29), the notions life and praxis (the dynamics of everyday life, Alltagsreligion) should be fundamental in theory formation for practical theological reflection. The reflection of believers within daily life experiences and actions (Alltagsreligion), can be viewed as a specific methodology in doing theology, specifically within an academic environment, focussing on theological teaching and education (Dillen \& Gärtner 2015:69-70). At stake is how one lives one's religion (ordinary religion) within spiritual practices. For Ed Farley (1983:21-41), lived religion, as a praxis matter in practical theological reflection, is a kind of habitus; a praxis mode of 'ecclesial redemptive presence' in worldly affairs.

In the words of Wilhelm Gräb (2011), 'the duty to be' implies faith as a dynamic of lived religion and praxis of divine experiences; religious experiences as an expression of 'piety' and humane self-understanding (Schleiermacher 1980). ${ }^{2}$ Burkhart (1983:56) argues that, for Schleiermacher, practical theology is the art of overcoming the distance between human life and what it is meant to be (the telic dimension of praxis).

With reference to recent developments, practical theology is viewed as an action science (Handlungswissenchaft) trying to

2.It is important to note that, for Schleiermacher, piety or godliness (Frömmigkeit) is not merely a subjective and internal psychic category. He links the concept of not merely a subjective and internal psychic category. He links the concept of
'schlechthinniges Abhängigskeitsgefühl' with an existential mode of living (Sosein); this existential mode of living contributes to a kind of togetherness of perceptive sensibility (Empfindlichkeit) and self-activity (Selbstätigkeit). This coincidence creates a self-awareness of dependency wherein God, as a powerful factor, becomes the instigator of piety (Frömmigkeit). Piety, as an expression of a unique mode of self-understanding within religious experiences, establishes a relationship of mutuality and reciprocal action:

... und dann bezeichnet das Selbstbewusstsein ein Verhältnis der Abhängigkeit; oder es schlägt um in einer Reiz zur Gegenwirkung, sei nun diese Widerstand oder leitende Einwirkung auf das bestimmende, und dann ist bezeichnet ein Verhältnis der Weschelwirkung oder Gegenwirkung. (Schleiermacher 1980:31) 
connect the Christian faith to the praxis and context of our modern or postmodern society (Heitink 1993:18). Communication and the empirical dimension of human actions (experiences of God) have become an important paradigm for practical theological reflection (Van der Ven 1990:139). ${ }^{3}$ De Gruchy (2001:3-4) adds the dimensions of transformation and the aesthetic in human actions, that is, our ability to transcend the visible through imagination. Browning (1991:105) calls this the meta-dimension of vision in practical moral thinking wise reasoning.

Faith is not without a reasonable basis and indeed embedded in rational constructions so to probe deeper into the realm of the Christian truth. Many theologians in the past referred to the fact that theologising is about testing and rethinking. 'A common conviction of these theologians, and of the classical theologian tradition generally, is that the Christian faith prompts inquiry, searches for deeper understanding, dares to raise questions' (Migliore 2004:2).

On the other hand, theology is not merely about critical reflection (scientia - rational knowledge). In theology, there is a close connection and interplay between science (reason) and wisdom (insight). According to Augustine, theology is also rooted in sapientia: the ability to respond by loving God, and to delight in communion with him as Charry (1993) formulates it:

The challenge is for the apostolic faith to capacitate believers to desire and delight in God so that their dignity, relationships to persons and things, and visions of human excellence and a just social order stem from delight. (p. 102)

Within an academic environment, the challenge is how to merge scientia and sapientia within the paradigmatic framework of theologising.

Practical theological reflection is also engaged in the interplay between practice, praxis and wisdom. Besides the performanceaction paradigm (liberating practices of transformation), the connection practice-praxis includes the creative interplay between wisdom and imagination (fides quaerens imaginem). Practice and action are exponents of practical reasoning and wise decision-making that are engaged in the healing and caring dimension of life (phronesis). ${ }^{4}$

Practice presupposes the telic dimension of meaning as enacted in praxis matters. It includes wisdom (sapientia) the knowledge of soulful devotion and the spirituality of compassion. Wisdom is about public life $\mathrm{e}^{5}$ issues. The interplay

3.Ganzevoort (2002:39) sees the human praxis of faith as the first order of reflection. 'It is the experiences and constructions of individuals and communities, responding to what they perceive, construct as coming from God, and their discourse about God and towards God.

4.Practical theology poses the question about the reason or intention of human actions as well as the norms and values that direct actions and influence decisions. In the context of the Christian faith within the dynamics of life, it is the question about phronesis: wisdom as the driving force behind the actions of communities of faith (Browning 1991:9-10).

5.Most scholars nowadays agree that practical theology, at its best, functions 'as a kind of public theology sensitive to the individual but directed toward the wider social area' (Miller-McLemore 2012:14). Clerical needs and hierarchical issues (Reader 2008) often dominated the practical theological discourse. Gradually there is a shift to normative dominated the practical theological discourse. Gradually there is a shift to
construction and practical engagement (action orientation) (Osmer 2008:4). between meaning and the existential realities of life are two sides of praxis thinking and the interconnectedness between faith and life, belief and practice. Praxis deals with the concrete: how and when and why certain actions are to be performed and certain insights to be appropriated. Praxis in Christian wisdom refers indeed to habitus. But habitus, then, in terms of Friedrich Schleiermacher' qualitative and religious category (So-sein), pointing to the spiritual realm of transcendence and meaning.

In the Christian tradition, habitus represents care (Sorge) and compassion. Faith is grace and love enacted as compassionate being-with the suffering of 'the frail other'. Thus, the research question in a practical theological epistemology: Can the wisdom of divine compassionate being-with be rendered as 'knowledge', and does it play a decisive role in practical theological research and sound methodology?

\section{The frailty of life: Context of practical theological reflection}

As researcher, the practical theologian, within the contours of ministry, is constantly exposed to the unexpected, not to be predicted events of human suffering, weakness, illness, frailty, death and dying. Therefore, the notion of the practical theologian as a very frail figure.

My assumption is that theological data are thus framed by, inter alia, 'theopaschitic knowledge' (the frailty of a suffering God - theologia crucis). The core praxis question in practical theological reflection is then how to link God with the praxis of human vulnerability (frailty), evil, injustice, helplessness, hopelessness and despair (theodicy question) (Louw 2016). For the latter, there is no reasonable answer possible on the level of rational factuality. In fact, theology is mostly more 'speechless' than explanatory.

Practical theologians, as researchers, are vulnerable and frail figures. They oscillate between 'empirical data' produced by the statistics of the human sciences and spiritual data delivered by the biblical narrative, confessions and dogmatic axioms of synods, church counsels and denominations. Therefore, the challenge in theological research: How do one merge the epistemological quest for epistemic truth with the realm of faith; with 'transcendent analyses' and meta-data (the realm of sapientia) related to human frailty and suffering?

\section{Epistemology: A disciplinary and scientific}

Epistemology, as the process of controlled knowing, refers to the how, what and sources for valid knowledge. In a scientific approach, epistemology refers to the specific ways in which different disciplines construct, interpret and represent knowledge in the world (Wisker 2008:68). The core question in epistemology is how one gains knowledge, and what is an appropriate source for human knowledge. 
It is inevitable that when one mentions the notion of science, the quest for knowledge (episteme) surfaces (De Freitas 2012:16). Science is about reliable information and valid knowledge with the following questions: How do I know (processes of knowing)? What are the sources for knowledge? How valid is the information? How will the information be disseminated? In this regard, philosophers have identified many types of knowledge: from propositional to nonpropositional, empirical to non-empirical (Moser 1999:273).

'Epistemic' is derived from the Greek word 'episteme' meaning authentic or true knowledge. According to Plato, the latter is contrasted to a mere opinion (Mouton 1996:9). According to the Greeks, knowledge originates through a sense of wonder and awa (verwondering). The epistemic demand correlates with a kind of yearning (hunkering) for truth. Both can be described as prescientific experience, fundamental to all forms of knowledge - also to scientific knowledge.

Epistemic truth in epistemology is closely related to the character of the very specific discipline (disciplinary identity) (Wisker 2008:68); thus, the imperative to get clarity on the character of the specific discipline in academic writing and theological research (Kilian 1985; Smith 2008).

Christian reflection is mainly informed by the written text of the Bible. The Bible narrates the knowledge of faith. Through narratives, one is informed by data referring to the transcendent realm of life as determined by what one can call the God-factor. Different images of God, conceptualisations in terms of human experiences and interpretations within various cultural contexts, shape and determine the epistemological framework of what can be called a Christian framework of knowledge. Epistemic truth in theological reflection cannot be separated from what one can call the presence of God in existential life events. And this knowledge must be interpreted within new cultural contexts and philosophical modes of wording and thinking.

But how can the interpretation of texts as connected to the spiritual realm of faith be linked to the demand for research and epistemic truth?

Our first task is to get clarity on what is meant by research and science so to detect whether practical theology qualifies as discipline within an academic environment and scientific approach to research and theory formation.

\section{Research: The art of critique - problematising the problematic field}

Every attempt to categorise the term research has become a nightmare. ${ }^{6}$ There are so many approaches possible. The notion of 'mixed-methods research' has become popular among researchers due to the notion of complexity. More and more the thesis is that research involves not only collecting,

6.Mouton (1996:13) defines scientific knowledge as follows: 'As a product or outcome of scientific research, scientific knowledge can be defined as the body of proposition (factual statements, hypotheses, models, theories, laws) which, at a specific time, is (factual statements, hypotheses, models, theories, laws) which, at a specific time, is
accepted by the scientific community (for instance the community of sociologists or psychologists), as being valid and reasonably correct.' analysing and interpreting both qualitative and quantitative data, but also integrating conclusions from those data into a cohesive whole (Leedy \& Ormrod 2014:268). ${ }^{7}$

In general, one can say that research includes all attempts of clearly formulated problems and by means of methodical collecting and systematic processing of data researchers strive to gain insights and design theories for critical reflection.

Research is about asking ${ }^{8}$ and beginning to respond to critical questions, seeking knowledge and understanding of the world and its processes, and testing assumptions and beliefs (Wisker 2008:51). For Leedy and Ormrod (2014:1-20) research is not merely gathering information; it is not merely rummaging around hard-to-locate information; research is not merely transporting facts from one location to another. Research does not merely document issues, organising data or summarising facts. Research questions critically problematise issues within a very specific formal field and discipline. Research should therefore be demarcated and requires clear articulation of a goal, a specific procedure and plan in the collection and interpretation of data in attempts to solve the problem that initiated the research. ${ }^{9}$

To conclude, scientific research is done to construct knowledge. ${ }^{10}$ Its aim is to refine theory formation ${ }^{11}$ and paradigmatic thinking. It systematises data and information by means of a described strategy of principles to study an issue of interest (Chilisa 2016:6). The spinoff of research is that it creates disciplinary language ${ }^{12}$ that leads to field comprehension and academic differentiation (identity of various disciplines).

7 Another very "new' kind of research is emerging namely Researching Online (Dolowitz, Buckler \& Sweeney 2008). Despite possible disadvantages, namely that (Dolowitz, Buckler \& Sweeney 2008). Despite possible disadvantages, namely that
electronic resources appear to reduce a student's ability to engage in rigorous electronic resources appear to reduce a student's ability to engage in rigorous
thinking; encourage 'academic laziness' (Rothenberg in Dolowitz et al. 2008: xii); inhibit the ability to engage actively in higher forms of analysis with the acute danger of losing the ability to see the links between information and lateral thinking the internet can still be an immensely useful resource (Dolowitz et al. 2008: xii).

8. Much research starts out from asking questions, considering and trying to solve problems, or constructing a hypothesis about how someone or something behaves or could behave; and then testing out, trying out, working on these problems, hypotheses, and so on, using research methodologies and methods. It is essential when you go into research to decide exactly what your research questions are (or you will find that you are merely collecting data). (Wisker 2008:55)

9.According to Wisker (2008), research presupposes inquisitiveness:

The cycle can start with experience or a problem; a theory or hypothesis; or a question; a fascination with trying to see how, why, if, in what ways, why not, what if? (p. 51)

10.Constructing knowledge is linked to the endeavour of theory formation. This assertion is also applicable to theological research. Theology itself is an endeavour of constructing knowledge and developing theories regarding the encounter between God and human beings to inform actions of faith in this world. Actions are pre-informed by appropriate theories; faith needs rational categories to understand pre-informed by appropriate theories; faith needs rational categorie
what is going on between faith in God and the demands of life.

11.In his book Client-centred therapy, Carl Rogers (1951:15) wrote: 'We have proven in our own experience Kurt Lewin's oft quoted statement that "Nothing is so practica as a good theory"'. Without theory, practice goes astray in the wild desert of experimentation, empirical probing, managerial skills and opportunistic practicalities.

12.Especially in theology, theory formation regarding our understanding of God's presence and divine interventions in life events are paramount. Conceptualisation is one of the cornerstones in theory formation. Thus, it is the attempt to find 'technical language' and 'grammar' that can describe the link between the content of religious belief systems and the happenstances of life. Theological research wants to gain clarity on the connection between human's understanding of God (God-image) and clarity on the connection between human's understanding of God (God-image) and the human quest for meaning and dignity within life events and painful modes of suffering. It wants to construct critical conceptions that will contribute to the poo of knowledge within the dynamics of a hermeneutical endeavour. It is thus of paramount importance for theological research to get clarity on basic issues like methodology and research methods, that will create valid sources of knowledge and reliable outcomes regarding the character of Christian faith, the scope of
Christian spirituality, and the destiny and hope of life (the teleological dimension). 
There are many types of research. When dealing with existential life issues and the meaning of life, research is done in a more qualitative than quantitative approach.

\section{Qualitative research - Probing into the codes of life}

It should be remarked that a clear description of the term is indeed difficult, because the term qualitative research encompasses several approaches to research that are in some respect quite different from one another. Yet, all qualitative approaches have two things in common. 'Firstly, they focus on the meaning and interpretation of phenomena that occur in natural settings - that is in the "real world". And secondly, they involve capturing and studying the complexity of those phenomena' (Leedy \& Ormrod 2014:141). Due to the factor of observation in qualitative studies, the use of case studies is very important in many research designs. 'In a case study sometimes calls idiographic research - a particular individual, program, or event is studied in depth for a defined period of time' (Leedy \& Ormrod 2014:143). Rather than nomothetic descriptions and the quest for quantification and exact statistics, qualitative research tends to be more heuristic, that is, probing - looking in depth at non-numerical data. The nature of this type of research is in the first place less deductive and more inductive; in other words, it does not stem from preformulated premises, but moves to the field of research by means of observation and unbiased interpretation.

Due to current developments in theory formation, and the upcoming notion of complexity and chaosmos in philosophical reflection on the scientific meaning of research, quality refers to the value and meaning of concepts and paradigms as embedded in cultural and intersubjective settings. The complexity of codes of life represent philosophies of life, ideas about life and the transcendent realm of schemata of interpretation.

Edgar Morin (2008:21) in his book On Complexity, points out that, in dealing with human problems, one has to reckon with the notion of hyper-complexity. 'But complexity is not only quantities of units and interactions that defy our possible calculation; it also is made up of uncertainty, indetermination, and random phenomena. Complexity is, in a sense, always about chance' (Morin 2008:20) ) $^{13}$ and therefore open to unpredictability that often supersedes rational analyses and positivistic predictions on the outcome and meaning of life.

Life is embedded in and framed by what Peter Berger (1992:121) calls 'signals of transcendence'. The questions where to and wherefore point to the quest for meaningful signals of transcendence. We each have a desire or need for something greater than ourselves; some bigger purpose or meaning in life. Berger (1992) states:

13.Within the framework of hermeneutical thinking complexity implies processes of complexification (Rescher 1998:56). Rather than the offering of 'cheap solutions", complexification describes the richness of experiences as embedded in paradox, it does not want to simplify, but to probe into the density of systemic networking (thick descriptions). Complexification is an attempt to understand the system in terms of its complementary parts despite obvious levels of contradiction (Collen 2003:61).
In openness to the signals of transcendence the true proportions of our experience are rediscovered. This is the comic relief of redemption; it makes it possible for us to laugh and to play with a new fullness. (p. 121)

Signals of transcendence create spiritual spaces for processes of hope when life seems to be merely the tragedy of a cul de sac.

Within the framework of hermeneutics and the circular approach regarding the interplay between texts and contexts as well as the accommodation of paradox or complexity in theory formation (complexification), rather than merely rationality and complification (the solution of problems), quality has become the complexity of interdisciplinary exchange of different approaches (multi-disciplinarity intradisciplinarity) and critical reflection on different schemata of interpretation.

The articulation of complexity points to a radical new way of thinking in theory formation. Rather than being analytic and reductionist within the split between subject and object, it calculates with the indeterminant factor within the happenstances of life. It is more interested in the collective, cooperative and organisational aspects of life. It focuses on integration in detecting wholeness. It tends to be synthetic and holistic within the dynamics of networking. (Davies in Montuori 2008: xxix). One can call this new paradigm 'the indeterminate or unpredictable physics of hope', because the focus is away from viewing the cosmos as a gigantic clockwork mechanism with each component slavishly and unfailing executing its programmed instructions to mathematical precision.

The implication is that research data, the description of phenomenon, human experience of life events and paradigmatic issues refer to more than merely empirical factuality. Data is embedded in a networking dynamic of complex systems. Even the methodology of phenomenological observation implies more than 'empirical' (the senses). In terms of the philosophy of existential phenomenology, phenomena also refer to essence and transcendental reflection (a spiritual and meta-dimension). This thesis can be verified by a closer look at the fundamental point of departure in existential phenomenology.

\section{The phenomenological dilemma in empirically based research: 'Observation' or transcendental probing - 'Wesenschau'?}

The tension between the subjectivity of human experience and the meaning dimension of life had been articulated by one of the founders of existential thinking in Christianity, namely Søren Kierkegaard. Existential knowledge must be both subjective and edifying - reasonable. According to Collins (1983:139), Kierkegaard sensed a danger in the empiricist stress upon objectivity and the discipline of existential experience. 
The philosopher, Martin Heidegger, dedicated his major work Sein und Zeit (1963) to the living realm of being and existential thinking. In this regard, the phenomenology of Edmund Husserl played a paramount role.

Heidegger made a bold statement by pointing out that phenomenology is not merely about observing and describing the appearances of phenomena. Phenomenology is fundamental an ontological endeavour probing into the meaning of being (Dasein) and detecting the essence of being (Sein des Daseins). Phenomenology is not merely a technical and mechanistic exercise (technische Handgriff) (Heidegger 1963:27) in epistemology, but a summing: back to the cause itself (zu den Sache selbst) (Heidegger 1963:27); the reality and signified essence within the pretence of the appearance (Schein) (Heidegger:28-29). ${ }^{14}$ The signified essence of life is demarcated by the existential phenomena of human vulnerability, exposure to frailty, anxiety, dread and fear of death. In this regard existential phenomenology reveal a meta-realm and transcendental structure in being (Dasein). Thus, the quest is for what Heidegger calls existential life care (Sorge).

Within philosophy, Edmund Husserl ${ }^{15}$ points out that phenomena cannot be deprived from the dimension of intentionality and meaning. Thus, the importance of transcendental analyses, that is the attempt to probe into the realm of intention and significance ${ }^{16}$ is a meta-physical kind of act probing into the essence of being. Phenomenology then act as an ontological performance into the spiritual realm of transcendence (pretended significance) as fundamental reality of being. As method, phenomenology is deeply a 'spiritual endeavour'.

Over and against empiricism with its sole focus on reality as merely a phenomenological reality to be observed by the senses (en-soi), Husserl poses that the observation of phenomena is embedded in a dialectic network of noësis (the awareness of meaning - bewuste betekenis) and noëma (object of observation with reference to its intended meaning - die betekende). The dialectics of noёsis and noёma transcends the parameters of the senses and points to the meta-realm of meaning. Within this noetical dialectics, existential knowledge implies meaning-identification (sinduiding).

Noetics is derived from the Greek nous [mind, intellect, understanding, reason, thought] and the verb noeō [apprehend, perceive, understand, and gain insight into]. In Christian

14.Phenomenon from the Greek phainomenon means to point to the fact that the appearance points to something (meaning, significance) as a kind of revelation (das Offenbarende). Phenomenology is thus the attempt to bring to light. The pretence of the appearance is not the essence, but an attempt to present reality that is not to be observed directly ("... aber "in Wirklichkeit" das nicht ist, als was es sich gibt') (Heidegger 1963:29). Transcendental analysis then means to probe into the original meaning or significance embodied in the phenomenon (pretended appearance).

15.See for a discussion on Husserl and his importance for an existential phenomenology, Luijpen (1964:108-110).

16.The notion of noetics and its relatedness to intentionality stems from the phenomenology of Edmund Husserl. 'Husserl's epochè, on the contrary, makes the world (the sense of the world) appear and discloses the essential structure of phenomenological consciousness which is intention' (Thèvenaz 1962:103). spirituality, apprehension is related to wisdom thinking and an understanding of the will of God. The Hebrew bin [to understand, perceive] refers to a process of judging and exploring the relation of things to one another (Harder 1978:124). As an indication of the soulfulness of our being human, nous is related to the function of making a true discernment in terms of a vivid awareness of the presence of God. Nous is closely related to sapientia - a kind of knowledge of the heart.

One can conclude in saying that nous in Christian wisdom thinking supersedes rational analyses with its claim of verification and empirical observation with its claim of experiential evidence. More than 'empiricism' is at stake.

\section{The empirical dilemma: The threat of empiricism}

With empiricism is meant the naïve presumption that evidence resides in the confirmation of facts by means of a mechanistic series of reasoning due to qualitative research based on conclusions derived merely on regularities that are supported by behavioural responses and personal, human experience. Empiricism is about the one-sided naivety of causality in research methodology, the so-called 'causality trap' and the verification obsession. It refers to 'epistemic arrogance' - the hubris concerning the limits of our knowledge (Taleb 2010:136); we overestimate what we know and underestimate uncertainty, by compressing the range of possible uncertain states (i.e. by reducing the space of the unknown) (Taleb 2010:140). ${ }^{17}$

Empiricism is about the simplification of life to experience and what we perceive; the reduction of life to factuality and human experience. What we cannot see (the unseen), what we cannot 'proof' and is related to unpredictability and the improbable, lie outside the framework of reflection and research. The spiritual realm and philosophical paradigm of wisdom lie outside the scope of valid and reliable knowledge. 'Here we look at the seen, what lies within the information set, and we examine the distortions in the act of processing it' (Taleb 2010:64). We have lost the realm of wisdom knowledge (sapientia), the art to 'see' the 'unseen' and the iconic view on life (Louw 2014) as well as to interpret signs and symbols pointing to the meta-realm of life. ${ }^{18}$

Wisdom thinking operates both within the realm of human experience and paradigmatic reflection. It reckons

\footnotetext{
17.According to Taleb $(2010: 8)$, the human mind suffers from three ailments. Taleb calls them the 'triplet of opacity', viz. the illusion of understanding, the retrospective distortion and platonification, (i.e. the tendency to platonify, namely liking known schemas and well-organised knowledge - to the point of blindness to reality) (Taleb 2010:131).

18.The philosopher Karl Jaspers introduced the notion of chiffre to the art of interpretation. Chiffre is about signs which signify 'transcendence', that which supersedes the senses and points to a beyond or metaphysical realm. Chiffre is inherent to our being and functions as the speech (Sprache) of reality that makes 'transcendence' visible (schaubar) and significant (deutbar) (Jaspers 1932:146-148). 'transcendence' visible (schaubar) and significant (deutbar) (Jaspers 1932:146-148). Through the notion of chiffre, the art of interpretation should take account of the fact that the whole of life and the cosmos are transparent for the ultimate, for a meaning that supersedes the senses and creates a kind of significance. For that matter, even art functions as a form of chiffre (Jaspers 1932:136); it attaches vision and significance to things. Thus, it is the reason why reality is fundamentally a 'spiritual entity' (geistige Realität) (Jaspers 1962:163). Life is an art describing a journey of spiritual poetics.
} 
fundamentally with the surprise of transcendent intervention and faithful creativity (spiritual imagination); it is acutely aware of the fact that human experience is embedded in the dynamic networking of noëma as well: paradigmatic frameworks of intended meaning. The dialectics of noetics presupposes the research methodology of hermeneutics. ${ }^{19}$

Taking the dimension of noetics into consideration, one can conclude by saying that a hermeneutic of life events operates within the duality of faith (believing - sapientia) and reason (knowing-scientia). Applied to research in practical theology, hermeneutics probes by means of heuristic acts of faith (fides quaerens) into the intended significance of actions of faith referring to what one can call the praxis of God.

Interpretation is inevitably a core ingredient of processes of knowing to detect the epistemic value of research data. In this regard, hermeneutics surfaces as a scientific approach to methodology in practical theology. This is the reason why the practical theologian, Martina Kumlehn (2011:20), calls practical theology an analysis of the religious praxis by means of a cultural and hermeneutical interpretation.

In a qualitative approach to research in practical theology, hermeneutics could be rendered as the most appropriate methodology to interpret texts, symbols and metaphors that are embedded in the realm of human and existential frailty, but at the same time are rendered as signals of transcendence related to religious experiences and processes of signification, probing the meaning of life. The latter can be called the quest for spiritual hermeneutics in the scientific demand for sound methodology in practical theological reflection.

One can conclude by saying that spiritual hermeneutics regarding the meaning of life, is fundamental to methodology in practical theological research. Faith-based knowledge in an academic environment within the framework of a spiritual hermeneutics is about 'faith seeking the understanding and interpretation of the meaning of life': fides qauerens vivendi. Practical theology is involved in a kind of 'imaginative poetics of life'.

\section{Spiritual hermeneutics: The quest for methodology ${ }^{20}$ in practical theological research}

The philosopher, Wilhelm Dilthey (1961:82), called the spiritual poetics in art 'imaginative poetry'. Imaginative

19.The polarities that have clouded the hermeneutical debate - dynamic versus static views of inspiration, propositional versus encounter theology, word versus sentence versus discourse models of communication, assertive versus poetic pproaches to literature, the author versus the text versus the reader as the enerating force of meaning - are not contradictory, but are independent parts of larger whole. Disjunctive thinking has created the crisis. Propositional content, sense and reference, intended meaning - all are viable and indeed necessary components of the hermeneutical enterprise (Osborne 2006:516)

Hermeneutics (Dilthey 1976:248-249) could therefore be described as the 'art of understanding'; it detects meaning as a relational category inherent in life; it comprehends life and the connections between part and whole (Hodges 1944:20).

20.In general, methodology is about a philosophical schema of interpretation to systematise human knowledge. In the field of research, methodology is inter alia viewed as '... the scientific actions, techniques and instruments you use to execute the research project by addressing the research problem and meeting the stated the research project by addressing the research poetry creates an awareness of transcendence and links experience to the symbolic meaning of life; it requires a kind of spiritual hermeneutics to discover meaning in life. Hermeneutics (Dilthey 1976:248-249) could therefore be described as the 'art of understanding'; it detects meaning as a relational category inherent in life; it comprehends life and the connections between part and whole (Hodges 1944:20).

'Understanding' in hermeneutics is not merely about knowledge as information, and thus a cognitive endeavour. Knowledge is embedded within the tension between subjectivity and objectivity; between researcher and intersubjectivity; between reason (cognitive dimension) and emotion (affective dimension; between goal (outcome) and motivation (conative dimension).

Hermeneutics is involved in the analyses of texts and the role of prejudices and previous horizons of understanding within the spiral interplay between reader, text and context, as Osborne (2006) states:
The polarities that have clouded the hermeneutical debate - dynamic versus static views of inspiration, propositional versus encounter theology, word versus sentence versus discourse models of communication, assertive versus poetic approaches to literature, the author versus the text versus the reader as the generating force of meaning - are not contradictory but are independent parts of a larger whole. Disjunctive thinking has created the crisis. Propositional content, sense and reference, intended meaning - all are viable and indeed necessary components of the hermeneutical enterprise. (p. 516)

One could say, the hermeneutical endeavour of the interpretation of data within different contexts is part and parcel of 'epistemic truths' in practical theological reflection and research methodology. This epistemic truth, to be still theological and not merely phenomenological, is closely related to what one can call the praxis of God. The latter refers to epistemic, spiritual truth of the compassionate being-with of the suffering God: the passio Dei within the frail life realm of existential realities.

\section{Phronesis [practical reasoning] within the framework of the praxis of God}

Practical theology is a 'functional' theology. It seeks a better understanding of, especially, the function fundamental to the praxis of God (the encounter between God and human beings). The fundamental form and structure within which this encounter between God and humans becomes apparent, is the church as the body of Christ, the fellowship of believers (koinonia). Practical theology is thus about the faith community's serving functions of ministry (diakonia) (functional or operational ecclesiology). The serving and ministerial functions within the process of spiritual communication (the object of research in a practical theology) are linked to the following theological and ecclesial functions - functions that describe and demarcate the notion of the praxis of God - God's active and salvific involvement in 
life events and engagement with human frailty, suffering and vulnerability based upon the so-called passio Dei.

The following praxis functions of faith could be identified in practical theological reflection:

- Kerugma: proclaiming the gospel (homiletics)

- Didache: spiritual education

- Paraclesis: care and compassion

- Oikodomein: edification and spiritual maturity

- Marturia: missional outreach

- Diakonia: charity and diaconic participation

- Koinonia: ecclesial fellowship

- Leitourgia: worship and celebration

- Xenodochia: congregation as hospitable and a safe haven for the silent victims of life

The previous practical theological directives are all indications of the basic functions of a practical theological ecclesiology, demonstrating the praxis of God, namely the covenantal and pneumatological encounter with human beings.

The previous basic functions are, theologically speaking, founded by the passio Dei as expression of the praxis of God. The praxis of God is about the compassion and comfort of a suffering God (theopaschitism), God incarnated in the frailty of our being human.

For the rabbis in the Jewish tradition the compassion and creativity of God were modalities of the divine presence in the world (Davies 2001:243). Compassion displayed an active and historical presence with and for Israel, serving in the formation of a holy fellowship of people who would be mindful of the covenant and reverently honour his name and faithful promises, as argued by Davies (2001):

As the signifier of a divine quality which can apply also to human relationships, the root $\mathrm{rhm}$ has much in common with the noun hesed, which denotes the fundamental orientation of God towards his people that grounds his compassion action. As 'loving-kindness' which is 'active, social and enduring', hesed is Israel's assurance of God's unfailing benevolence. (p. 243)

The passio Dei, in its connection to the praxis of God, defines 'practice' in theology and missiology to compassion ( $\mathrm{rhm}$ in close connection to the root hnn which means to be gracious). Together with oiktirmos and praxis, the passio Dei expresses the being quality of God as connected to human vulnerability and suffering (Esser 1976:598).

The above-mentioned theological praxis of God, enfleshes in ecclesial functions, could be viewed as spiritual indicators for doing research in practical theology. They describe the intentions of the practical theologians as 'frail researchers'. Frail, because the concepts represent a kind of spiritual healing and compassionate engagement for restoring, maintaining, and guiding human beings into modes of hopeful living. In a nutshell: The ecclesial praxis functions are intentional. They intend (telic dimension) to promote and instil human dignity; they are indicators for a praxis of
Christian, spiritual humanism and operate within a bottom-up approach - from the frailty of grassroots experiences to the normativity of the praxis of God..$^{21}$

The spiritual conceptualisation of life should be seen as theoretical frameworks for doing practical theology. They represent paradigmatic categories as related to the praxis of divine intervention and engagement with human frailty within ecclesial contexts: understanding or interpreting; communication or verbalising; acting; hoping; imagining, seeing, beautifying and living. They set the contours for conceptualisation; they demarcate the contours of praxis language and grammar for methodology in a practical theological epistemology.

\section{Conclusion}

In De Trinitate (books XII-XIV), Augustine distinguishes between scientia (God's judgement which implies rationality) and sapientia (to enjoy God's grace; 'delight in the grace of God' [Charry 1993:91-92]). In light of this distinction made by Augustine, one can conclude that the relationship between scientia and sapientia introduces a healthy tension in theological methodology: the tension between experience and revelation; between empiricism and transcendence; between rationality and wisdom; between critical reflection and awe.

Theological science can be nothing but theology, and theology, on the other hand, nothing but reflection on the meaning of faith (intellectusfidei) (Jüngel 1972:13) and the appropriateness of God-images (Louw 2016). This reflection engenders a further tension which affects especially theological training: the tension between academic theology in a university faculty and congregational theology as a church function and ministerial enterprise.

Theologising consists of scientia (rational-historical analyses of experiential data), sapientia (wisdom and reflection or contemplation about the transcendent dimension of faith); and intelligentia (comprehension and cognitive analysis along the lines of a logical and philosophical argumentation). Should both scientia and intelligentia be separated from sapientia, theology could easily degenerate into either a rationalistic practice (speculation) or a sensory enterprise (empiricism).

Truth in wisdom thinking is relational and contextual. However, it is not necessarily relativistic and subjectivistic or culturally restricted as in the case in philosophical epistemology as proposed by Foucault (1995:443-452) and Derrida (1981:3-59). Due to the faith context of biblical wisdom, knowledge cannot be reduced to merely socio-biological processes and functional utilism as proposed by Dawkins (1995:111-155) - the term God serves merely a utility function.

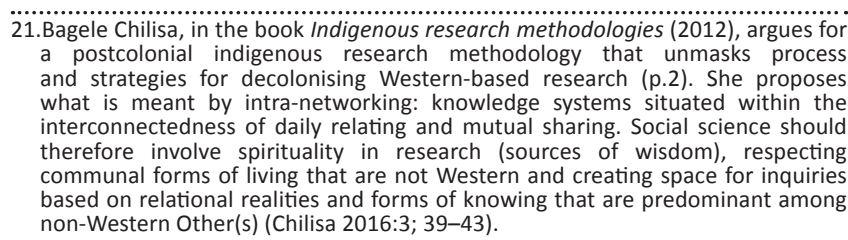
1.Bagele Chilisa, in the book Indigenous research methodologies (2012), argues for a postcolonial indigenous research methodology that unmasks process and strategies for decolonising Western-based research (p.2). She proposes what is meant by intra-networking: knowledge systems situated within the terconnectedness of daily relating and mutual sharing. Social science should communal forms of living that are not Western and creating space for inquiries non-Western Other(s) (Chilisa 2016:3; 39-43). 
A hermeneutical approach in practical theology that refers, inter alia, to the biblical text as source of knowledge within a Christian understanding of epistemology, implies more than merely 'pure empirical data. In fact, phenomenology presupposes probing into the transcendental and meta-realm of life' (Husserl: Wesenschau) - the telic dimension of noësis. A qualitative approach in research methodology should not be reduced to sheer 'empiricism'. With empiricism is meant the naïve presumption that evidence resides in the confirmation of facts by means of a mechanistic series of reasoning and conclusions derived merely on regularities that are supported by behavioural responses and personal, human experience. It is imperative that a qualitative approach to the interpretation of research data should take into consideration the meta-realm of meaning and the impact of paradigms on processes of conceptualisation.

Science or scientia (rational critical reflection) and wisdom or sapientia (phronesis - the intention in human acts and behaviour) should be maintained in theory formation for practical theological research models.

Due to the meta-realm of meaning, worldviews, ideology and existing patterns of thinking (paradigmatic networking), hermeneutics should be rendered as fundamental to all kinds of methodology in scientific research for theory formation in practical theology. That should be the case when research in practical theology opts for an interdisciplinary approach and a 'mixed-methods research'. The latter has become popular amongst researchers due to the notion of complexity.

To maintain both its spiritual-theological character (ministerial and ecclesial context) and its relevancy for the dynamics of life events (contextuality), a 'spiritual empiricism' is proposed by means of a praxis of practical theological verbing: understanding and interpreting; communicating and verbalising; acting; hoping; imagining, seeing, beautifying and living. These verbs demarcate what can be called the praxis of God in practical theological reflection.

The argument is that insight in the structures and functions of an operative ecclesiology will help caregivers, ministers and researchers in practical theology to understand their professional identity in distinction of the disciplinary identity of other professional people, all working together within a team approach to the profession of helping and healing.

\section{Acknowledgements Competing interests}

The author declares that he has no financial or personal relationships which may have inappropriately influenced him in writing this article.

\section{References}

Bauerschmidt, F.C., 2013, Thomas Aquinas: Faith, reason and following Christ, Oxford University Press, London.

Berger, P.L., 1992, A far glory: The quest for faith in an age of credulity, The Free Press, New York.
Browning, D.S., 1983, 'Pastoral theology in a pluralistic age', in D.S. Browning (ed.), Practical theology, pp. 187-202, Harper \& Row, San Francisco, CS

Browning, D.S., 1991, A fundamental practical theology, Fortress, Minneapolis, MN.

Burkhart, J.E., 1983, 'Schleiermacher's vision for theology', in D. Browning (ed.), Practical theology, pp. 42-60, Harper \& Row, New York.

Charry, E.T., 1993, 'Academic theology in pastoral perspective', Theology Today 50(1), 90-104. https://doi.org/10.1177/004057369305000111

Chilisa, B., 2016, Indigenous research methodologies, Sage, Los Angeles, CA.

Collen, A., 2003, Systemic change through praxis and inquiry, Transaction Publishers, New Brunswick.

Collins, J., 1983, The mind of Kierkegaard, Princeton University Press, Princeton, NJ.

Davies, O., 2001, A theology of compassion: Metaphysics of difference and the renewal of tradition, Eerdmans, Grand Rapids, MI.

Dawkins, R., 1995, River out of Eden, Phoenix, London.

De Freitas, T.M., 2012, 'Epistemology and the use of scripture in pastoral care and counselling', DTh thesis, Faculty of Theology, Stellenbosch.

De Gruchy, J.W., 2001, Christianity, art and transformation: Theological aesthetics in the struggle for justice, Cambridge University Press, Cambridge.

Derrida, J., 1981, Dissemination, Athlone Press, London.

Dillen, A. \& Gärtner, S., 2015, Praktische theologie: Verkenningen aan de grens, Lannoo Campus, Leuven.

Dilthey, W., 1961, Die Philosophie des Lebens: Eine Auswahl aus seinen Schriften, Teubner Verlag, Stuttgart.

Dilthey, W., 1976, W. Dilthey selected writings, ed. transl. and introduced H.P. Rickman, Cambridge University Press, Cambridge.

Dolowitz, D., Buckler, S. \& Sweeney, F., 2008, Researching online, Palgrave Macmillan, Houndmills.

Esser, H-H., 1976, 'Splanchna', in C. Brown (ed.), Dictionary of new testament theology, vol. 2, pp. 599-601, Paternoster, Exeter.

Farley, X. (ed.), 1983, 'Theology and practice outside the clerical paradigm', in D.S. Browning (ed.), Practical theology, pp. 21-41, Harper \& Row, San Francisco, CA.

Foucault, M., 1995, 'Power/Knowledge', in J.P. Sterba (ed.), Social and political philosophy: Classical western texts in feminist and multicultural perspectives, $\mathrm{pp}$. 443-452, Wordsworth, Belmont, NY.

Ganzevoort, R.R., 2002, 'WYSIWYG: Social construction in practical theological epistemology', Journal of Empirical Theology 15(2), 34-42.

Gräb, W., 2011, 'Lebensinn und die Frage nach Gott', in T. Klie, M. Kumlehn, R. Kunz \& T. Schlag (hrsg.), Lebenswissenchaft Praktische Theologie?! Praktische Theologie im Wissenschaftsdiskurs, pp. 79-96, Band 9, De Gruyter, Berlin.

Harder, G., 1978, 'Soul', in C. Brown (ed.), Dictionary of New Testament Theology, vol, 3, p. 686-687, Paternoster, Exeter.

Heidegger, M., 1963, Sein und Zeit, Max Niemeyer Verlag, Tübingen.

Heitink, G., 1993, Praktische Theologie, Kok, Kampen.

Hernandez, W., 2006, A spirituality of imperfection, Paulist Press, New York.

Hodges, H.A., 1944, Wilhelm Dilthey: An introduction, Kegan Paul, Trench, Trubner, London. Jaspers, K., 1932, Philosophie, Dritter Band, Metaphysik, Verlag von Julius Spinger,
Berlin.

Jaspers, K., 1962, Der Philosophische Glaube angesichts der Offenbarung, Piper Verlag, München.

Jüngel, E., 1972, Unterwegs zur Sache, Kaiser, Munchen.

Kilian, J., 1985, Form and style in theological text, University of South Africa, Pretoria.

Kumlehn, M., 2011, 'Einleitung: Praktische Theologie als Lebenswissenschaft?!', in T. Klie, M. Kumlehn, R. Kunz \& T. Schlag (hrsg.), Lebenswissenchaft Praktische Theologie?! Praktische Theologie im Wissenschaftsdiskurs, Band 9, pp. 1-8, D Gruyter, Berlin.

Leedy, P.D. \& Ormrod, J.E., 2014, Practical research: Planning and design, 10th edn., Pearson Education, Essex.

Louw, D.J., 2014, Imaging the Unseen: On beauty of life, body and soul, Sun Media, Stellenbosch.

Louw, D.J., 2016, Wholeness in hope care: On nurturing the beauty of the human soul in spiritual healing, Lit Verlag, Wien.

Lues, L. \& Lategan, L.O.K., 2006, Re: Search ABC, Sun Press, Stellenbosch.

Luijpen, W., 1964, Existentiële fenomenologie, Aula-Boeken, Utrecht.

McGaughey, D.R., 1998, Christianity for the third millennium: Faith in an age of fundamentalism and skepticism, International Scholars Publication, San of fundamentisco, CA.

McGaughey, D.R., 2007, Religion before Dogma: Groundwork in practical theology, Bloomsbury T\&T Clark, London.

Migliore, D.L., 2004, Faith seeking understanding: An introduction to Christian theology, 2nd edn., Eerdmans, Grand Rapids, MI.

Miller-McLemore, B.J., 2012, 'Introduction: The contributions of practical theology', in B.J. Miller-McLemore (ed.), The Wiley-Blackwell companion to practical theology, pp. 1-20, Oxford, Malden.

Montuori, A., 2008, 'Foreword: Edgar Morin's path of complexity', in E. Morin (ed.), On complexity, pp. vii-xliv, Hampton Press., Cresskill, NJ. 
Morin, E., 2008, On complexity, Hampton Press, Inc., Cresskill.

Moser, P.K., 1999, 'Epistemology', in R. Audi (ed.), The Cambridge dictionary of philosophy, Cambridge University Press, Cambridge.

Mouton, J., 1996, Understanding social research, Van Schaik, Pretoria.

Nilson, F., 2007, 'Towards a dialectic complexity framework: Philosophical reflections', in K.A. Richardson \& P. Cilliers (eds.), Explorations in complexity thinking Pre-Proceedings of the 3rd International Workshop on complexity and philosophy pp. 236-249, ISCE Publishing, Mansfield.

Osborne, G.R., 2006, The hermeneutical spiral: A comprehensive introduction to biblical interpretation, IVP Academic, Downers Grove, IL.

Osmer, R.R., 2008, Practical theology: An introduction, Eerdmans, Grand Rapids, MI.

Reader, J., 2008, Reconstructing practical theology: The impact of globalization, Ashgate, Aldershot.

Rescher, N., 1998, Complexity: A philosophical overview, Transaction Publishers, Brunswick.
Rogers, C.R., 1951, Client-centered therapy, Houghton Mifflin, Boston, MA.

Schleiermacher, F.D.E., 1980, Der Christliche Glaube nach der Grundsätzen der evangelischen Kirche im Zusammenhange dargestellt (1821-1822), Teilband 1, Walter de Gruyter, Berlin.

Smith, K.G., 2008, Academic writing and theological research, South African Theological Seminary Press, Johannesburg.

Taleb, N.N., 2010, The black Swan: The impact of the highly improbable, Penguin Books, London.

Thèvenaz, P., 1962, What is phenomenology? Quadrangle Paperback Original, Chicago, IL. Van der Ven, J.A., 1990, Entwurf einer empirischen Theologie, Kok, Kampen.

Van der Ven, J.A., 2002, 'An empirical or normative approach to practical-theological research', Journal of Empirical Theology 15(2), 5-33. https://doi.org/10.1163/ $157092502 \times 00018$

Wisker, G., 2008, The postgraduate research book handbook, Palgrave Macmillan, Houndmills. 